\title{
Dreaming the circle: indigeneity and the longing for belonging in White Australia
}

\section{Jane Mulcock}

In settler-descendant societies indigenous identity becomes a powerful and a fraught symbol of belonging to place. Multiple voices negotiate its meaning, make claims and counter-claims, extend invitations and deny access. One Australian says 'we are all indigenous to somewhere. My ancestors were Scottish'. He says 'here, in the bush, where I was born, where I grew up, I can feel the spirits watching me'. ${ }^{1}$ Another says 'I am seventh generation Australian. I am indigenous. I am proud'. ${ }^{2}$ In court, in a native title dispute, a White forester says ' $M y$ family has lived here for generations ... I have the right to camp, hunt and fish ... My father taught me how'. ${ }^{3}$ Many voices challenge these statements of non-Aboriginal belonging, call them colonial, call out against the crime of appropriating identity. And then an Aboriginal custodian negotiating for land in another native title claim says to the Australian court: 'We have a gift we have been trying to give you ... We want to fill up your emptiness with meaning so that you can love us and our country. We want to teach all Australians about their belonging in this country ... before it's too late' $^{4}$ The circle spins and spins, its constant grinding friction sets deep emotions aflame.

The concepts of indigeneity and belonging are intimately entwined, woven together in conversations about attachment to place, about nationalism and love of country, about 'soil, blood and identity'. 5 This meshing and merging leads to slippages of meaning, and to the raw and salty conflicts that sometimes flare out of contesting definitions. Most readers would probably agree that when it comes to land, indigeneity begets belonging. To be indigenous, is after all, to be autochthonous, to be born of the land. But what of ancestral connections? In settler societies like Australia or New Zealand or Canada not all of us born of the land can easily call ourselves indigenous. Our colonial histories have led to situations where descendants of the prior inhabitants, the peoples displaced by colonial incursions and settlements, have the first, and many argue the only, claim to indigenous status. However, as those settlements grow to be five or six or seven generations deep the concept of indigeneity is increasingly contested. Once a source of shame for some, it is now a source of pride for many of those who can claim it, a sign of resilience and embeddedness, a sign of deep belonging, desired more than discouraged, proclaimed more than disguised. At least among those for whom belonging to place is an important source of personal identity. 
'So', some people ask, 'how many generations does it take to become indigenous to a chosen homeland?' Perhaps there is another term that those of us not descended from aboriginal inhabitants (in the general sense) might use to describe our particularly unsettled state of belonging and not belonging; the fact remains, however, that some settler descendants are increasingly trying on indigenous identities as a way of understanding and describing the strong feelings of attachment to place that they experience. This emergent indigeneity (with a lower case ' $i$ ') is usually described as different from or separate to Australian Aboriginal Indigeneity (with an upper case ' $\mathrm{I}$ ' to denote its currency as a highly specific and politicised identity marker). Settler descendant claims to indigeneity usually seem to refer instead to the more generic category of being 'native-born' 6

In the course of undertaking ethnographic fieldwork that required me to participate in a range of workshops and events focused on Indigenous spirituality, I began to recognise patterns of identification amongst the other 'non-Indigenous' participants. These people typically expressed strong feelings of attachment to particular places, or to 'nature' in a more general sense. Many wanted to find ways of expanding those feelings of belonging through ritual. They looked to the traditions of Indigenous peoples as an obvious starting point, as a source of inspiration and guidance for the development of a personal, nature-based form of spiritual practice. While some Indigenous people themselves reject this interest, dismissing it as another form of colonisation, as theft, appropriation, rape, ${ }^{7}$ others choose to work with it, to see it as an opportunity for education, for increased respect and understanding. In doing so, however, this latter group of individuals sometimes cross highly sensitive boundaries associated with the construction of politically powerful and exclusive Indigeneities. By deliberately embracing, engaging or encouraging 'non-Indigenous' interest in Indigenous spirituality they risk transgressing some of the borders that other Indigenous people and their supporters rigorously defend. ${ }^{8}$

The widespread idea, based both on myth and reality, that Indigenous peoples have an intimate (and) spiritual relationship with nature that White people living in industrial societies have lost, has a long history. ${ }^{9}$ In North America and Europe, Native Americans especially have, often inadvertently, provided inspiration for White people trying to express their own feelings of attachment to nature and to land. ${ }^{10}$ Since the early 1900s, North American children have been encouraged to learn about the natural environment by becoming 'Camp Fire Boys and Girls' and dressing as 'Indians'. In Europe, networks of 'hobbyist' groups have long allowed adults to enact their fascination with Native American indigeneity through costume and performance. ${ }^{11}$ This Western intellectual tradition - based on widely accepted beliefs about entrenched differences (and hidden similarities) between the categories of White and Indigenous ${ }^{12}$ — has led to instances where people born into the former category have claimed they 
belonged in the latter. ${ }^{13}$ Perhaps the most famous of these is 'Grey Owl', an English-born man who adopted a Native American persona in the 1920s and achieved celebrity status as a public lecturer and writer, bringing Indigenous perspectives on nature, spirituality and the need for environmental conservation to White audiences in Europe and North America.

Over the last few decades these ideas about indigeneity and ecological wisdom have been enthusiastically embraced by the environmental movement ${ }^{14}$ and by the alternative health and spirituality (or New Age) movement. ${ }^{15}$ Contemporary Paganism and Shamanism bridge these two groups with their particular focus on the development of historically grounded nature-based religions that locate humans firmly within the natural world. ${ }^{16}$ In these contexts Indigenous spiritual beliefs and practices have been widely represented as a way of entering into or becoming part of the natural landscape, a means of 'reconnecting' to the earth and to an imaginary pan-human, pre-Christian past when nature-based religion was the only religion and all people (supposedly) lived in harmony with their environments. ${ }^{17}$

Such representations of Indigenous people have been closely tied to processes of colonialism and to common-sense interpretations of evolutionary thought. But what of Indigenous peoples themselves? What of Indigenous agency? How might these stereotypical representations be reclaimed and re-written by representatives of the groups being depicted? How might they be utilised as teaching devices to provide interested White people with a more realistic understanding of contemporary Indigenous cultures? How might the deliberate and careful sharing of Indigenous spiritual traditions by Indigenous people themselves constitute a transgression of colonial relations?

In August 1996, I attended a day-long workshop in Perth, Western Australia, entitled 'The Ancient Wisdom of Aboriginal Women'. The participants were a group of 50 White migrant and Australian-born women aged somewhere between 20 and 70 years. The facilitator was Tjanara Goreng-Goreng, an Aboriginal woman from Queensland. The strong attachments to, or 'feelings for', land expressed during the day by several women who had lived in rural Australia for long periods of time struck me as particularly significant. These statements about emotional bonds to place reminded me of a workshop I had attended two months earlier called 'Belonging and Being in Australia'. In that instance, David Mowaljarlai, a senior Ngarinyin man from the Kimberley region of Western Australia, was the guest of honour, and the focus of the event was on the similarities between Aboriginal and non-Aboriginal identity in Australia. These two workshops provided the foundation for my study of ideas about indigeneity, belonging and spirituality among a selection of Australian-born people of Anglo-Celtic ancestry. ${ }^{18}$ The varying, and often very active, contributions that 
Aboriginal Australians made to the evolution of these same ideas played a key role in my interpretations of the material I collected.

The following stories, drawn from my fieldnotes, illustrate some of the ways in which the series of workshops run by the Aboriginal facilitator from Queensland challenge the boundaries of I/indigeneity by offering those of us who would usually be described as 'non-Indigenous' the opportunity to truly belong, to overcome the ambiguities of settlement and ancestry by adopting an Aboriginal framework of inclusivity, a framework that accepts and promotes the true belonging of all people living in Australia through beliefs about the all-embracing nature of ancestral spirits and of the land itself.

Jarrahdale, Western Australia, May 1997. ${ }^{19}$

White voices sing out into the dusk chill, sing in an Indigenous language, songs from Northeast Queensland. Feet dance on winter wet grass, on long settled Noongar soil. White feet. And one pair of Goreng-Goreng Waka-Waka feet. Women's feet. Women's voices.

White hands shake green branches, new growth pulled from eucalyptus trees. White bodies pass through eucalyptus smoke. Around eucalyptus fire. White minds drawn, seduced, liberated, discomfited by Indigenous ritual. Women's ritual. Women's songs. Women's dance. Women's company. Indigenous company.

This Aboriginal woman generously gives us permission to belong, because we were born here, because we have lived here. Courageously and with no apology, she asks us to belong.

By running workshops on Aboriginal spirituality for non-Aboriginal women around Australia, Tjanara Goreng-Goreng makes a particular contribution to processes of reconciliation. She welcomes the interest that participants express in Aboriginal beliefs and practices and she shares some of her own knowledge with them in return. Questions of belonging circulated around the room at each of her workshops, sometimes explicit, sometimes not. Closely linked to this topic was a kind of search for indigeneity, a desire to find points of connection or commonality with Aboriginal people at a spiritual or emotional level, usually through the prism of attachment to land.

Thirty-five women gathered together on a cold night, many of us strangers. Sitting in a circle in a small hall surrounded by tall trees. A little uncertain, a little hesitant, a little excited. Why are we all here? Our Aboriginal leader asks each one of us to tell the group why we have come: to learn about Aboriginal culture; for healing; for spiritual connection; because it felt right. These are our reasons.

Tjanara makes a circle on the carpet with white ochre. She sings in her traditional language and we copy her. She shows us how to dance and we dance. One woman 
describes a wailing ceremony that she has heard about. She has experienced much loss and asks if we will wail with her.

We are divided into three age groups. Twenty of the women present are older than forty years. Together they form the outer circle. They are the senior women. Thirteen of the remaining group are between forty and thirty. They form an inner circle. Only two of us are left, both 'babies' under thirty. We sit in the middle, in the embrace of our elders.

The group was also divided on another axis, those who had been to previous workshops led by this facilitator and those who had not. The weekend gathering described here was called 'Sacred Circles, Sacred Dreaming' and was promoted as a follow-up to 'The Ancient Wisdom of Aboriginal Women'. The implication was that those of us who had done the first workshop were ready to progress to the next level of knowledge. In an interview a few days before the Jarrahdale event, Goreng-Goreng told me that she felt non-Aboriginal women came to her workshops because of a desire for female companionship, for community and for the healing that can come from being in community. She also felt that they came out of an awareness that they were living on Aboriginal land and that part of her responsibility was to show them the positive aspects of Aboriginal culture. Ritual and ceremony were an important part of this process, and something that she felt was missing for women in (so-called) Western societies. She also incorporated more standard forms of learning in her programs.

We sit on the floor and listen to Tjanara's introduction to the workshop. She tells us that everyone born in Australia belongs to the land and to the Rainbow Serpent that travels through the land. She also explains, for those born overseas, that the Rainbow Serpent takes in whoever chooses to put down roots in this country. She tells us that Aboriginal people have a responsibility to teach non-Aboriginal Australians, to share some of their spiritual knowledge with us so that we will better understand our own place in the world. She tells us stories about the Dreaming, how the continent was formed, how Aboriginal law was passed down through generations. She talks about songlines and sorcery and love magic, about the power of women and their knowledge of childbirth, about the way that a child's spirit comes up through the land and into its mother's body. We listen quietly.

The night darkens. We hear about recent Aboriginal history, about missions and colonisation, about suffering and fear and disease and oppression, about brutality and surveillance, devastation and imprisonment. About traumatised children and suicide, assimilation, acculturation. Carefully, we ask questions.

Difficult, delicate, negotiations of belonging are under way in contemporary Australian society. The tensions surrounding these negotiations are rooted in the long histories of Aboriginal and European thought and in the shorter history of Australian colonisation. They simultaneously draw together, emerge from, and produce a set of highly contested feelings and beliefs about what it means 
for those of us who are not of Aboriginal descent to belong to a place that was once stolen from, and is now shared - at least officially - with, Aboriginal people. Belonging is a fraught topic in settler societies. While Indigenous peoples have moral rights to belong based on primary associations with place that stretch back to a vanishing point far in the distance, colonial power relations have ensured that their cultural, economic and political belonging in the nation state is much more tenuous. On the other hand, as willing citizens, settlers and their descendants usually have clear claims on the cultural, economic and political fronts, but their belonging to place, to the land they inhabit, cannot be taken for granted.

In the morning we make our way back to the hall. The air is still crisp but the sun is warm. Spirits have lifted. The room is very different in the daylight, bright and airy. We begin with singing and dancing. Tjanara does some healing work and draws us back into our circles of the night before. Some of the women wail and cry, releasing hidden grief, safe and comfortable in the company of the group. This outpouring of emotion runs its course. Our leader encourages and soothes us with a healing ritual when it is over.

After lunch we sit down again together, this time to sew. We make headbands from red fabric and have white ochre designs painted on our faces. Then we move outside.

We sit in two semi-circles on the grass, the older women separated from the younger women, facing each other but slightly apart. Tjanara, our leader calls us forward one by one. She ties our headbands on, embraces each of us and whispers the name of an animal totem. When the last woman has been embraced she asks us to re-group according to the totems she has given us. She lights a small fire on the ground and lays green eucalyptus leaves over the top for a smoking ceremony. Solemnly, she asks each of us to step through the smoke, promising to ourselves as we go that we will do no evil to others. By the time we finish, dusk is falling again, the evening chill is setting in. To celebrate we dance the Water Dreaming and Leaf dances that we learned the night before until the fire dies down. Finally we move back into our age-based circles and pledge to support and help the people around us by following the three rules of the Dreaming that Tjanara recited for us: respect yourself; respect others; respect the land. In the growing darkness we bow our heads and close our eyes while she sings a sacred song to complete our ritual.

Winter wet grass, bare feet, women's voices. 


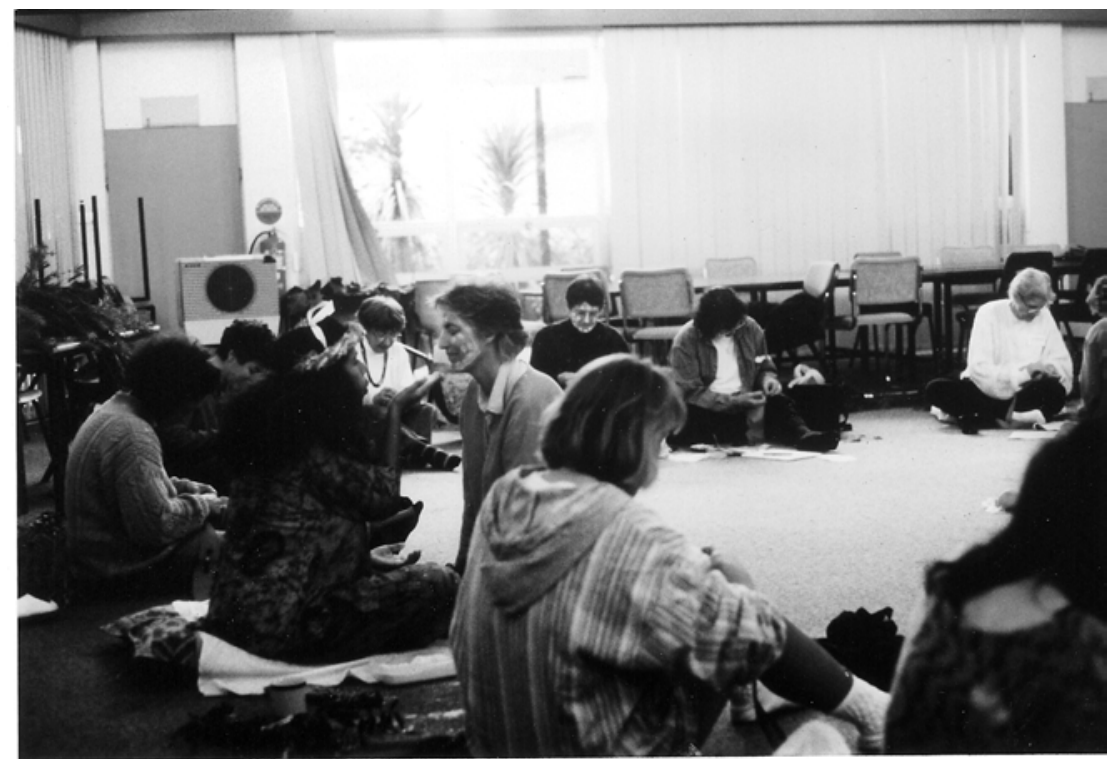

Figure 4.1: Face painting in the sewing circle Photograph by J Mulcock

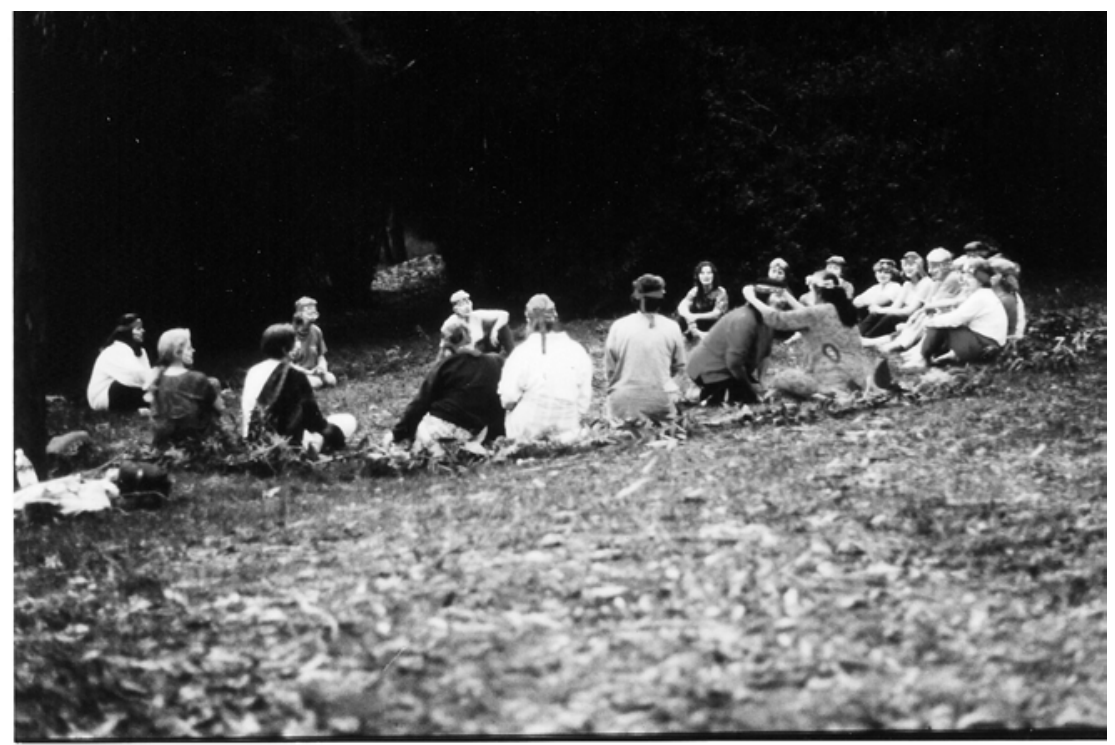

\section{Figure 4.2: Our headband ceremony}

Photograph by J Mulcock 


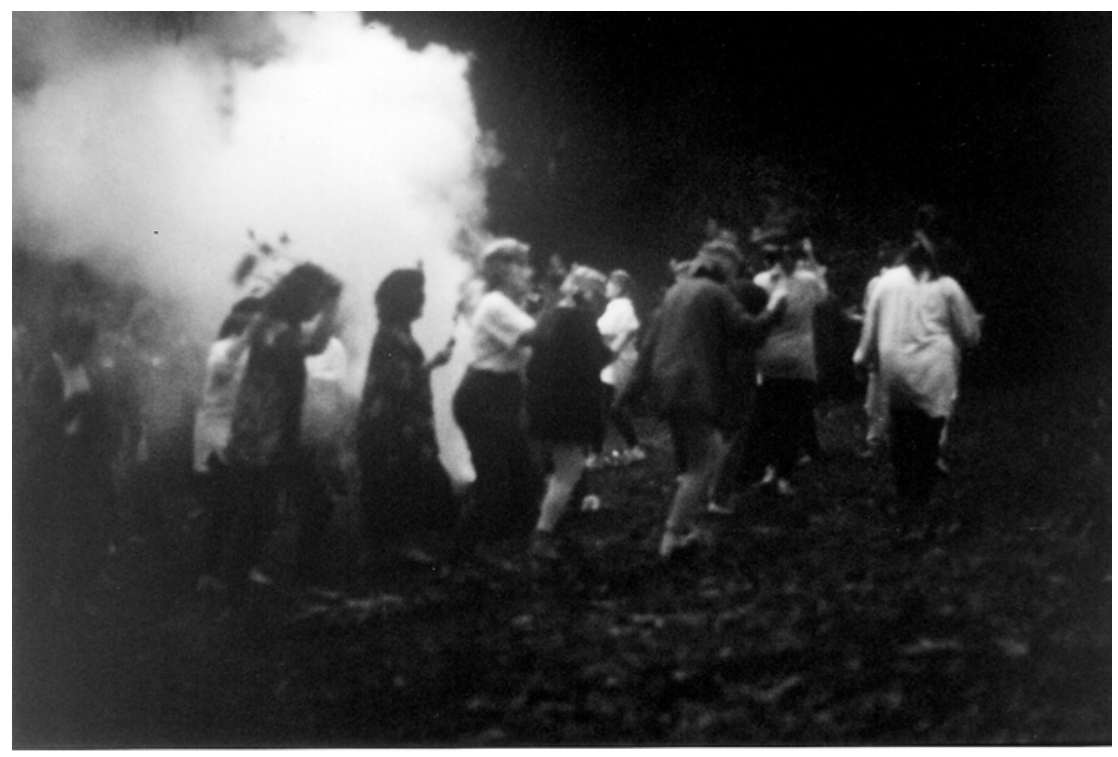

Figure 4.3: Women dancing Water Dreaming

Photograph by J Mulcock

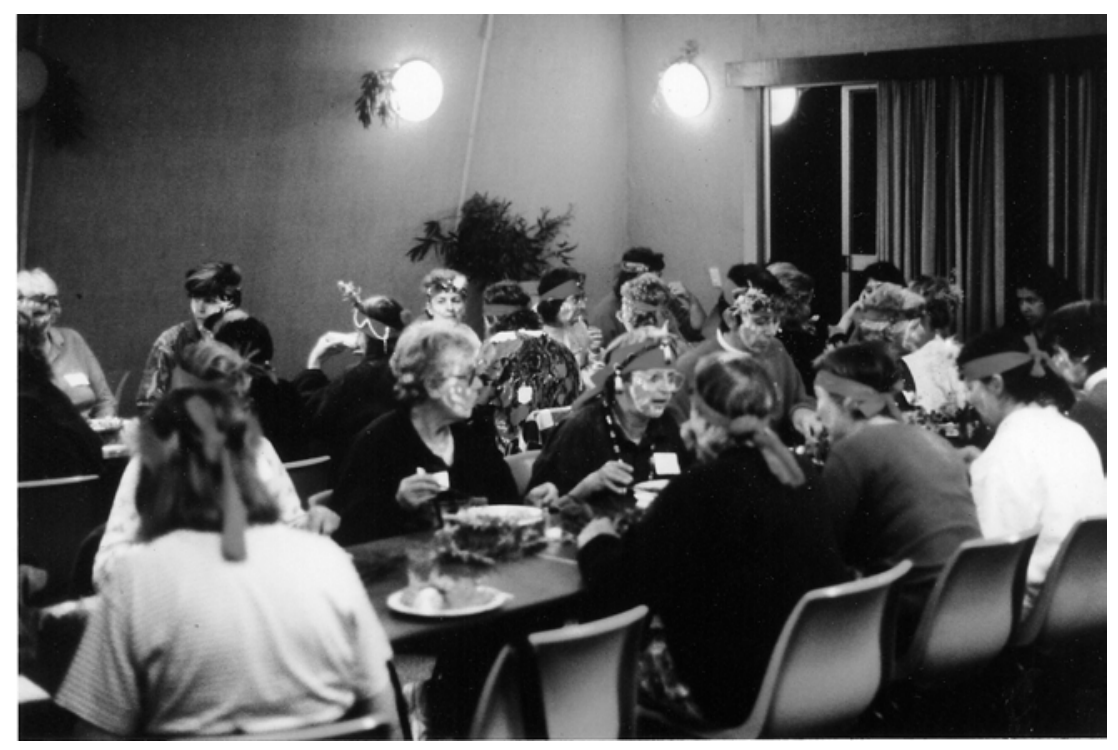

Figure 4.4: Evening meal in ochre

Photograph by J Mulcock 
The communal meal that evening was marked by a certain euphoria. Every woman (except Tjanara) chose to leave her ochre face paint on. The atmosphere was one of excitement and release. A storytelling session after dinner kept many of women together until late in the evening.

The final day began with a minute of silence in recognition of the Noongar people upon whose land we were sitting. The morning session focused on Aboriginal spiritual healing practices and in the afternoon we made dancing belts which Tjanara tied around our waists in a ritual similar to that of the day before. She told us that the belts were symbols of achieving womanhood. She also emphasised that none of this was equivalent to initiation, a misinterpretation that had occurred at one of her previous workshops. We returned to the dancing ground for a farewell ceremony where we again formed into our totem groups and danced and sang together. Tjanara drew us into a circle for the last time and asked us to say good bye to each other silently, one by one, promising as we did so to look after one another forever because now we were sisters.

There is an important epilogue to the story of the Jarrahdale workshop. I always sensed that the workshop facilitator's acknowledgement of non-Aboriginal belonging was a much welcomed message at each of the gatherings I attended. When I later interviewed some of the other participants, a few of them confirmed this intuition by talking about the significance of this woman's input for the development or unfurling of their personal sense of belonging to place.

One participant, Susan, ${ }^{20}$ went so far as to write 'Noongar' in brackets next to 'Australian' when asked to nominate her primary cultural identity on a form provided as part of the interview - even though she stated that her actual ancestry was, to her knowledge, all Anglo-Celtic. She told me that the Aboriginal workshop facilitator had helped her to recognise her own indigeneity and spoke with intensity about her sense of spiritual belonging in the south-west of Western Australia. Susan related strongly to Noongar author and artist Sally Morgan's account of 'discovering' her Aboriginality as an adult, ${ }^{21}$ reporting that she too had long carried the feeling that 'something was missing' from her life. ${ }^{22}$

Susan became increasingly interested in Aboriginal culture and spirituality after she started to study the healing powers of Western Australian wildflowers. Her adult experiences of using bush flower essences to deal with stress and emotional trauma, combined with her vivid childhood memories of spending time in the bush around her outer suburban home in Perth, evoked what she described as an 'innate feeling of belonging' to the Australian landscape. Susan compared this feeling with the attachments to land described by Aboriginal Australians. She explained that using Western Australian wildflower essences had helped her to recognise her own attachment to place, and her desire 'to belong to the 
Indigenous people' of the area where she was born and raised. ${ }^{23}$ This search $^{2}$ for an indigenous self ${ }^{24}$ coincided with, or perhaps grew out of, Susan's search for her 'inner self', a search that took shape as part of her efforts to cope with the increasing pressures of a busy urban lifestyle and a difficult marriage. Susan believed that using and learning about Western Australian wildflower essences helped her to 'come full circle', to re-establish the connections that she had with 'the bush' during her childhood.

The night before our formal interview, Susan phoned to express some of her concerns about talking to me and to emphasise the importance of what she was going to tell me. One of the things she challenged was my conceptualisation of Indigenous and non-Indigenous cultures in Australia as two separate categories. She felt this distinction was unsustainable, given that many so-called 'non-Indigenous' people were also born in Australia and felt a strong attachment for the country. When I asked her to expand on this observation in the interview, she talked about feelings of belonging and not belonging to place, firstly by comparing her family's experiences of feeling 'at home' whilst travelling through the Australian desert with the unease of the American friends they were with, and secondly by referring to her own and other people's feelings of discomfort when living away from their countries of birth. Susan's interactions with the Aboriginal workshop facilitator from Queensland strengthened and justified her sense of belonging by providing an explanatory framework that she was receptive to.

Amber and Diane, ${ }^{25}$ two of the other women I interviewed who had participated in the Jarrahdale workshop, spoke in similar ways about their desire to 'belong' to the land and the 'permission' to do so that they felt that the Aboriginal facilitator provided. Both in their late forties with teenage children, these women were close friends. They were also artists and liked to spend time together in the bush painting, working with textiles or taking photographs. Amber especially reported strong feelings of attachment to, or engagement with, some of the places that they visited. For example, she described a number of events that she believed were encounters with spirits in the landscape, suggesting that they were similar, 'in a way', to those reported by Aboriginal people she knew. ${ }^{26}$

Amber made several very clear statements about her understandings of the links between indigeneity and belonging to place when she articulated a strong desire to 'connect' with Aboriginal people as part of the process of connecting to Australian land. Here are her words.

I think that it's important for me to make that connection with Aboriginality because I live in this land, I am here, through a whole set of circumstances that I don't know really anything about, but I'm here, $I^{\prime} m$ in this land and unless I make a connection with the people who are 
connected with this part of the earth then I think I'm lacking something in my life. ${ }^{27}$

Amber suggested that at one point in her life she had hoped that she would find evidence that she was of Aboriginal descent, although the experience of working closely with Aboriginal people over several years eventually allowed her to understand and accept her difference. She made very strong associations between Indigenous people, spirituality and emotional or psychological involvement in the landscape. As I listened to her talk about her own spiritual experiences in the bush, I thought I heard an undercurrent of awkwardness, perhaps embarrassment, related to her non-Indigenous status - as if her feelings and perceptions were less believable or less valid because of her Anglo-Celtic ancestry.

Diane also reflected independently on the links between Aboriginality, non-Aboriginal identity and feelings of belonging in Australia. She told me that the more she learned about Aboriginal people the more uncertain she became about her own belonging in Australia. Diane expressed a kind of postcolonial guilt about European invasion of Aboriginal country alongside an assured statement about her right 'to live here'. This was followed by an acknowledgement of the significance that Tjanara Goreng-Goreng's inclusive approach to belonging held for her:

Tjanara said to us ... 'if you were born here then you are part of the land'. I felt so happy when she said that, I really did, it was like relief. ${ }^{28}$

Amber and Diane also talked about a much earlier encounter with a Noongar women from Denmark in south Western Australia, who argued that all people living in Australia were part of the Aboriginal Dreaming regardless of ancestral background. ${ }^{29}$ It seemed that this experience had also been formative in the development of Amber's and Diane's ideas about indigeniety and belonging. The workshop confirmed some of these ideas and further supported the notion that non-Aboriginal Australians could 'truly belong' to the Australian continent.

These desires for, or expressions of, a kind of non-indigenous indigeneity have not come out of the blue. They are not unique or even particularly surprising. Rather they are part of a bigger picture that encompasses two centuries of contact between settlers (i.e. invaders), their descendants, Aboriginal people, and the landscape itself. Related processes of indigenisation were evident, for example, in the 1930s in the poetry of the Jindyworobaks, a group of writers who advocated the development of a truly Australian literary tradition. ${ }^{30}$ A similar theme pervaded the contemporaneous work of well known artist Margaret Preston who encouraged Australian artists to 'be Aboriginal' as a means of establishing a unique 'national art'. ${ }^{31}$ More recent examples of Australian settler descendant claims to a kind of indigeneity have also been documented, often in 
the context of public conversations about national identity. Growing interest among non-Aboriginal Australians in native plants and animals, support for Aboriginal sporting heroes, and curiosity about Aboriginal spirituality, culture and identity have all been interpreted as part of a national process of indigenisation. ${ }^{32}$

Over the last decade or so anthropologists, historians and literary scholars have begun the task of documenting and analysing non-Indigenous feelings of belonging to land in Australia, New Zealand and the Americas. ${ }^{33}$ These writers consider assertions of settler descendant indigeneity, the feelings of attachment associated with being 'native-born', as genuine, valid attempts to understand and communicate a particular kind of relationship to 'adopted' country. An important issue that becomes apparent through their work is the lack of descriptive language available for talking about these sensitive and often contested attachments to place. The words 'indigenous' and 'native' have become so embedded in political discourses about the rights of first nations that they can no longer be used - at least in settler societies - in a purely descriptive, apolitical sense. ${ }^{34}$ As suggested earlier, these terms have become entwined in moral discourses about true (i.e. spiritual) belonging to land in such locations. This means that when someone, Aboriginal or non-Aboriginal, suggests that it is possible to truly belong to a place regardless of indigenous heritage, she or he steps across an invisible boundary that carries considerable political currency and is rigorously defended by those who would like it to be impermeable.

The stories recounted here of the workshops run by an Aboriginal facilitator, and the responses of some of the participants from those workshops, thus illustrate two transgressive movements around the idea of indigeneity, two attempts to renegotiate and destabilise the boundaries, to push the concept beyond its commonly perceived limits. The non-Aboriginal transgression is obvious. ${ }^{35}$ By publicly identifying too closely with indigeneity or Aboriginality in the course of claiming a kind of spiritual belonging to place, the women participants I refer to above are breaching a highly politicised boundary that is marked out and defended through accusations of appropriation, theft and misrepresentation. These accusations, delivered by one sector of the Aboriginal community and their supporters, are heavily informed by a postcolonial politics of minority identity requiring the exclusion and denouncement of any 'inauthentic' claims to belonging - the (implicit) argument being (at least in part) that the unique moral status of the group will be eroded if membership is not strictly monitored. ${ }^{36}$

But there is another logic at play, a logic lodged in discourses of spirituality and belonging, particular discourses of affect or emotion that work against political rationalities, rubbing and niggling at them like uncomfortable clothing on sunburned skin. This is the logic promoted by individuals like the Aboriginal 
woman who ran the workshops described above, active cultural agents who might be thought of as 'border crossers' ${ }^{37}$ Goreng-Goreng's transgression lies in her willingness to allow, to even encourage, a kind of belonging to place that it is not tied to indigeneity - at least in the sense of Aboriginal ancestry. When she publicly states that anyone born in Australia belongs to the land, she subtly undermines another Aboriginal / academic narrative that tells us the only way to truly belong in Australia is to be of Aboriginal descent. ${ }^{38}$ Others in the Aboriginal community share similar opinions on this issue.

Over several years I have collected quotes attributed to Aboriginal people from around Australia that support the idea of non-Aboriginal belonging to the land. I did not set out to look for such material and I did not even really notice it until I finally sat down to collate and synthesise the data I had gathered. The variety of concurring Aboriginal voices surprised me - and the quality that seems to unite them is a clear public focus on spiritual life. I relate some of these perspectives here.

Diana James, a white woman who has worked and lived for many years with Pitjantjatjara people quotes her Aboriginal teacher, Nganyinytj, as saying,

[I]f we were born in this country, our spirits weren't sent in fast delivery post packs across from England or Yugoslavia or wherever else. They're from here and we might be standing up in white skin or looking like we come from Greece but, actually, our spirit is of here and this is what we have to acknowledge and we have to get in tune with. It's important that people really look below the skin and start to connect at the heart level, to work together for creating a new spirituality, a new sense of place and strength that is truly Australian, that wells up from the ground. ${ }^{39}$

Wenton Rabuntja, a Pitjantjatjara man, is quoted by a journalist as arguing that all Australians belong to the Dreaming in which they were born - no matter what their heritage might be. Rabuntja says that place of birth is most important for place of belonging.

If our kids go over to America or some other place and Australian kid born there, well he's part of that one and that Dreaming and he's traditional where he was born. His borning place is number one. ${ }^{40}$

In each of these instances it is possible that the translations are imprecise or the people doing the translating are misinterpreting what they have been told. The following quote, however, comes directly from a speech that Ngarinyin elder David Mowaljarlai made to the Federal Court as a part of his native title claim over land in the Kimberley region of Western Australia. He said: 
We don't want to hurt you because you were born here in Australia, so you belong in Australia. But you have to learn about the culture of Australia so you know your own belonging, your naming and your identity. It's no good if you stay ignorant of the culture of this land, while your belonging is overseas. The Law for this land is recorded in the land. We can teach you that law. That way you won't be strangers in your birth country. ${ }^{41}$

I have also heard a senior Noongar man, Noel Nannup, tell audiences that everyone who has been in Australia for longer than six years belongs to the land. Finally, Wiradjuri woman Maisie Cavanagh reflected on this issue of belonging at a presentation I attended - although her comments were a little more cautious. She pointed out that Aboriginal people don't have a monopoly on a land-based spirituality and that all Australians can experience feelings of belonging to places. She also commented, however, that the feeling of belonging that comes from having generations and generations of extended family in one place is different from the feeling of belonging that one individual coming to a place from elsewhere can experience. Perhaps she is suggesting that attachment to place is not necessarily the same thing as belonging?

Together, these perspectives indicate that some Aboriginal people believe in the value of sharing part of their cultural knowledge about belonging to land with non-Aboriginal people. By extending some of their spiritual beliefs to incorporate Australians who are not of Aboriginal descent, these individuals provide a new framework through which to continue negotiations. By allowing for the possibility that non-Aboriginal people do truly belong to the land where they were born or where they have chosen to put down roots, and that this belonging doesn't have to undermine Aboriginal belonging in any way, they seem to be inviting new levels of engagement and mutuality in which they are the experts: they seem to be saying 'We are your teachers and this is your spiritual land too. Be in relationship with it. Accept responsibility. Care for it'.

The crossing of politically sensitive borders that mark off symbolically loaded social categories is a transgressive act. Tjanara and the women attending her workshop move across the borders of indigeneity and belonging in different directions. The former reaches towards the latter and vice versa. This movement can be interpreted in both positive and negative ways depending on whether the reader favours the logic of the 'border guards' ${ }^{42}$ or the 'border crossers'. There are plenty of Aboriginal voices raised in opposition to non-Aboriginal belonging - these voices tend to be loud and strategic, they tend to be part of a strong and resistant public discourse overtly focussed on political and social injustice. (I am not suggesting that politics is without spirituality or vice versa, but that some people choose to privilege one over the other in their public lives.) 
Other, quieter, voices also talk of injustice and ways of overcoming it by growing the respect that some non-Aboriginal Australians have for Aboriginal people. But I think they include an additional message - about the importance of also growing the respect that non-Aboriginal people have for themselves, for their attachment to the land that nurtures them, for their spiritual lives and the spiritual lives of others.

Like them or hate them, settler discourses of belonging and indigeneity are probably here to stay. Not only do they have a long history, but now the voices of Aboriginal people can also be heard in the public domain, some giving support through their own understandings of the importance of settler belonging, of spiritual belonging as a source of responsibility to land and people, blood and soil. Loose parallels can be drawn with the logic of nationalism and patriotism and, perhaps at the opposite end of the political spectrum, with the logic of deep ecology proposed by some environmental philosophers (often influenced in turn by their exposure to Indigenous philosophies). ${ }^{43}$ These Aboriginal voices are being hungrily embraced by those non-Aboriginal Australians who are engaged in their own spiritual search for belonging to place, a search that is perhaps inevitable in settler societies with the kind of violent and dispossessing history of Australia, perhaps part of a deeper settling, a more thorough acceptance of place and history.

By opening our ears and minds to the stories that people tell about their spiritual encounters with Aboriginal people, in this case with Goreng-Goreng through her workshops for women, it is possible to detect something of the heartfelt 'longing for belonging' ${ }^{44}$ present in Australian settler descendant discourse. Politically acceptable or not, it exists. This search, this quest, this process, and all its implications, should no longer be ignored or dismissed. The time to engage with it is now.

White faces, painted with white ochre. Queensland Ochre. Totems whispered, remembered. Over the warmth of a hot meal, the excited chatter of women renewed. White women. Indigenous woman. Australian women.

\section{Acknowledgements}

Thanks are due to Tjanara Goreng-Goreng for reading this paper at short notice and providing permission for her name and words to be used. Thanks also to each of the other anonymous interviewees referred to in this paper, all of whom contributed generously to my research.

\section{References}

Ashcroft, Bill, Gareth Griffiths and Helen Tiffin 1989, The Empire Writes Back: Theory and practice in post-colonial literature, Routledge, London. 
Bauman, Zygmunt 1992, 'Soil, blood and identity', The Sociological Review 40(4): 675-701.

Behrendt, Larissa 1998, 'In your dreams: cultural appropriation, popular culture and colonialism', Law: Text: Culture 4(1): 256-279.

Bell, Avril 1999, 'Authenticity and the project of settler identity in New Zealand', Social Analysis 43(3): 122-143.

Bowman, Marion 1995, 'The noble savage and the global village: cultural evolution in New Age and Neo-Pagan thought', Journal of Contemporary Religion 10(2): 139-149.

Butel, Elizabeth 1985, Margaret Preston: the art of constant rearrangement, Penguin in association with the Art Gallery of New South Wales, Ringwood, Victoria.

Churchill, Ward 1994, Indians Are Us? Culture and genocide in Native North America, Common Courage Press, Maine.

Cuthbert, Denise and Michele Grossman 1996, 'Trading places: locating the indigenous in the New Age', Thamyris 3(1): 18-36.

Deloria, Philip 1998, Playing Indian, Yale University Press, New Haven.

Dominy, Michèle 1995, 'White settler assertions of native status', American Ethnologist 22(2): 358-374.

2001, Calling the Station Home: Place and identity in New Zealand's high country, Rowman \& Littlefield Publishers, Lanham.

Dyer, Richard 1988, 'White', Screen 29(4): 44-64.

Eggington, Robert 1996, 'Intellectual property rights: the question of cultural ownership: a Noongar perspective', Noongar Karnadjil 1: 14.

Ellen, Roy 1986, 'What Black Elk left unsaid: on the illusory images of Green primitivism', Anthropology Today 2(6): 8-12.

Elliot, Brian 1979, The Jindyworobaks, Portable Australian Authors series, University of Queensland Press, St Lucia, Queensland.

Feest, Christian (ed.) 1989, Indians and Europe: An interdisciplinary collection of essays, Alano Verlag, Aachen.

Francis, Daniel 1992, The Imaginary Indian: The image of the Indian in Canadian culture, Arsenal Pulp Press, Vancouver.

Frankenberg, Ruth (ed.) 1997, Displacing Whiteness: Essays in social and cultural criticism, Duke University Press, Durham, NC.

Goldie, Terry 1989, Fear and Temptation: The image of the indigene in Canadian, Australian and New Zealand literatures, McGill-Queen's University Press, Kingston. 
Green, Rayna 1988, 'The tribe called Wannabee: Playing Indian in America and Europe', Folklore 99(1): 30-55.

Greer, Germaine 2003, 'Whitefella Jump Up: the shortest way to nationhood', Quarterly Essay 11: 1-78.

Hamilton, Annette 1990, 'Fear and desire: Aborigines, Asians and the national Imaginary', Australian Cultural History 9: 14-35.

Harvey, Graham 1997, Listening People, Speaking Earth: Contemporary Paganism, Wakefield Press, South Australia.

Hume, Lynne 2000, 'The Dreaming in contemporary Aboriginal Australia', in G Harvey (ed.), Indigenous Religions: A companion, Cassell, London: 125138.

Ilcan, Suzan 2002, Longing in Belonging: The cultural politics of settlement, Praeger Publishers, Westport.

Jacobs, Jane 1994, 'Earth honouring: Western desires for Indigenous knowledges', Meanjin 53(2): 305-314.

James, Diana 1996, Recorded lecture, Australian Transpersonal Institute National Conference, Sydney.

Kehoe, Alice Beck 1990, 'Primal Gaia: primitivists and plastic medicine men', in J Clifton (ed.), The Invented Indian: Cultural fictions and government policies, Transaction Publishers, New Brunswick: 193-210.

Krech, Sheppard 1999, The Ecological Indian: Myth and history, Norton, New York.

Lattas, Andrew 1990, 'Aborigines and contemporary Australian nationalism: primordiality and the cultural politics of otherness', Social Analysis 27: 50-69.

— 1991, 'Nationalism, aesthetic redemption and Aboriginality', The Australian Journal of Anthropology 2(3): 307-324.

1992, 'Primitivism, nationalism and individualism in Australian popular culture', in J Arnold and Bain Attwood (eds), Power, Knowledge and Aborigines, La Trobe University Press, Bundoora: 45-58.

Luhrmann, Tanya 1994, Persuasions of the Witch's Craft: Ritual magic in contemporary England, Picador, London.

Maddock, Kenneth 1991, 'Metamorphosing the sacred in Australia', The Australian Journal of Anthropology 2(2): 213-232.

Mies, Maria 1993, 'White man's dilemma: his search for what he has destroyed', in M Mies and V Shiva (eds), Ecofeminism, Spinifex Press, Melbourne: 132-163. 
Milton, Kay 1998, 'Nature and the environment in Indigenous and traditional cultures', in D Cooper and J Palmer (eds), Spirit of the Environment: Religion, value and environmental concern, Routledge, London: 86-112.

Miskimmin, Susan 1996, 'The New Age movement's appropriation of Native spirituality: some political implications for the Algonquian Nation', The Papers of the Algonquian Conference 27: 205-211.

Morgan, Sally 1987, My Place, Fremantle Arts Press, Fremantle.

Morton, John 1996, 'Aboriginality, Mabo and the republic: indigenising Australia', in Bain Attwood (ed.), In the Age of Mabo: History, Aborigines and Australia, Allen \& Unwin, St Leonards, New South Wales: 117-135.

Morton, John and Nicholas Smith 1999, 'Planting indigenous species: a subversion of Australian eco-nationalism', in K Neuman, $\mathrm{N}$ Thomas and $\mathrm{H}$ Eriksen (eds), Quicksands: Foundational histories in Australia and Aotearoa New Zealand, University of New South Wales Press, Sydney: 117-135.

Mowaljarlai, David 1995, 'We have a gift', Nova: Western Australia's Holistic Journal 2(9): 29.

Mulcock, Jane 2001, '(Re)discovering our indigenous selves: the nostalgic appeal of Native Americans and other generic indigenes', Australian Religious Studies Review 14(1): 45-64.

_ 2002, 'Searching for our indigenous selves: belonging and spirituality in Anglo-Celtic Australia', Unpublished PhD thesis, University of Western Australia.

Mulcock, Jane and Yann Toussaint 2002, 'Memories and Idylls: Urban reflections on lost places and inner landscapes', Transformations $2,<$ http://transformations.cqu.edu.au/journal/issue_02/pdf/MulcockToussaint.pdf $>$

Neuenfeldt, Karl 1998, 'Aboriginal didjeriduists in Australian education: cultural workers and border crossers', Journal of Intercultural Studies 19(1): 519.

Paine, Robert 2000, 'Aboriginality, authenticity and the settler world', in A Cohen (ed.), Signifying Identities: Anthropological perspectives on boundaries and contested values, Routledge, London: 77-116.

Plumwood, Val 2000, 'Belonging, naming and decolonisation', Ecopolitics: Thought and Action 1(1): 90-106.

Probyn, Elspeth 1996, Outside Belongings, Routledge, London.

Read, Peter 1994, 'Joy and forgiveness in a haunted country', New Norcia Studies: 1-9.

_ 1996, Returning to Nothing: The meaning of lost places, Cambridge University Press, Cambridge, UK. 
2000, Belonging: Australians, place and Aboriginal ownership, Cambridge University Press, Cambridge, UK.

Richards, Dave 1995, 'Whitefella Dreaming', HQ Magazine, May/June: 60-67.

Root, Deborah 1996, Cannibal Culture: Art, appropriation, and the commodification of difference, Westview Press, Colorado.

Rose, Wendy 1992, 'The great pretenders: further reflections on white shamanism', in MA Jaimes (ed.), The State of Native America: Genocide, colonization, and resistance, Race and Resistance Series, South End Press, Boston: 403-421.

Sackett, Lee 1991, 'Promoting primitivism: conservationist depictions of Aboriginal Australians', The Australian Journal of Anthropology 2(2): 233-246.

Sowelu, Daniel 2001, 'Maxine Fumagalli dies', Nova: Keeping Body and Soul Together 8(5): 28.

Taylor, Bron 1997, 'Earthen spirituality or cultural genocide? Radical environmentalism's appropriation of Native American spirituality', Religion 27: 183-215.

Thomas, Nicholas 2001, 'Appropriation/appreciation: settler modernism in Australia and New Zealand' in Fred Myers (ed.), The Empire of Things: Regimes of value and material culture, School of American Research Press, Santa Fe: 139-163.

Torgovnick, Marianna 1997, Primitive Passions: Men, women and the quest for ecstasy, Alfred A. Knopf, New York.

Trigger, David 2002, 'Indigeneity, ferality and what "belongs" in the Australian bush: nature, culture and identity in a settler society', Conference paper presented at the International Sociological Association XV World Congress, Brisbane.

\section{ENDNOTES}

1 Interview by the author, Leederville, Western Australia, 29 October 1996.

2 Informal conversation with the author, Burrup Peninsula, 1 October 2002.

3 Cited in Trigger 2002: 4.

4 Mowaljarlai 1995: 29.

5 Bauman 1992.

6 Read 1994; Dominy 1995; Trigger 2002.

7 For example Behrendt 1998; Miskimmin 1996.

8 For example Eggington 1996; Rose 1992; Green 1988.

9 Kehoe 1990; Francis 1992; Mies 1993; Deloria 1998; Feest 1989.

10 Torgovnick 1997: 139.

11 Deloria 1998.

12 For discussion of 'Whiteness' (in contrast to 'Blackness') see for example Dyer 1988; Frankenburg 1997. 
13 For some contemporary Australian examples see Mulcock 2001.

14 See Milton 1998; Ellen 1986; Sackett 1991; Jacobs 1994.

15 See Deloria 1998; Root 1996; Torgovnick 1996; Hume 2000.

16 For example Luhrmann 1994; Harvey 1997; Bowman 1995; Taylor 1997.

17 See Krech 1999 for a historical critique of this idea.

18 Mulcock 2002.

19 Unless otherwise indicated, italicised text denotes loosely reconstructed descriptions based on my fieldnotes and my memories of attending these events.

20 'Susan' is a pseudonym.

21 Morgan 1987.

22 Interview by the author, Winthrop, Western Australia, 13 June 1997.

23 See Mulcock and Toussaint 2002.

24 Mulcock 2002.

25 'Amber' and 'Diane' are pseudonyms.

26 Interview by the author, Mosman Park, Western Australia, 30 August 1997.

27 Interview by the author, Mosman Park, Western Australia, 30 August 1997

28 Interview by the author, Mosman Park, Western Australia, 14 August 1997.

29 Sowelu 2001

30 Elliot 1979.

31 Butel 1985: 50; Thomas 2001: 141.

32 Morton and Smith 1999; Morton 1996; Hamilton 1990; Lattas 1990, 1991, 1992; Maddock 1991; Goldie 1989.

33 Read 1996, 2000; Morton 1996; Dominy 1995, 2001; Trigger 2002; Paine 2000; Bell 1999; Ashcroft, Griffiths and Tiffin 1989; Greer 2003.

34 Paine 2000

35 Some Aboriginal commentators would also argue that Goreng-Goreng's actions are transgressive; as a teacher working alone rather than in the physical company of her community, as a Queenslander teaching in Western Australia, as an Aboriginal teacher willing to share cultural knowledge with non-Aboriginal students.

36 For example Churchill 1994; Deloria 1998; Cuthbert and Grossman 1996.

37 Neuenfeldt 1998; Mulcock 2002.

38 For example, Interview with Aboriginal historian Jackie Huggins, Late Night Live, ABC Radio National 2003.

39 James 1996.

40 Cited in Richards 1995: 67

41 Mowaljarlai 1995: 29.

42 Bauman 1992: 678.

43 For example, Plumwood 2000.

44 Probyn 1996; Ilcan 2002. 